ART IKEL

E-ISSN: $2615-5028$

\title{
PENERIMAAN MASYARAKAT SEBAGAI HASIL SINERGI HUMAS DAN MEDIA MASSA
}

\author{
Diah Fatma Sjoraida \\ (FIKOM Universitas Padjadjaran, diah.fatma@unpad.ac.id) \\ Edwin Rizal \\ (FIKOM University of Padjadjaran; edwin.rizal@unpad.ac.id)
}

\begin{abstract}
This research discusses how public relations from energy companies can utilize mass media so that their existence can be accepted by the community. This research was conducted in a village in Bekasi Regency which is an agricultural area on the outskirts of Jakarta. In general, this research is based on descriptive and qualitative methods. The results showed that the socio-economic life in the village changed but the community could accept it. The factors that led to the company's acceptance were because the public relations of the company while working with the mass media carried out a strategy by launching CSR programs, absorbing labor, and awareness of future orientation to the surrounding community. Even so, the public still complained about the comfort of living around the factory.
\end{abstract}

Keywords: corporate social responsibility, public relations, mass media

\begin{abstract}
Abstrak
Penelitian ini membahas bagaimana humas dari perusahaan energi dapat memanfaatkan media massa sehingga keberadaannya dapat diterima oleh masyarakat. Penelitian ini dilakukan di suatu desa di Kabupaten Bekasi yang merupakan daerah pertanian di pinggiran Kota Jakarta. Secara umum, penelitian ini mendasarkan pada metode deskriptif dan kualitatif. Hasil penelitian menunjukkan bahwa kehidupan sosial ekonomi di desa tersebut berubah namun masyarakat dapat menerimanya. Adapun faktor-faktor yang menyebabkan diterimanya perusahaan tersebut adalah karena pihak humas dari perusahaan tersebut sambil bekerja sama dengan pihak media massa melakukan strategi dengan meluncurkan program csr, menyerap tenaga kerja, dan penyadaran akan orientasi ke masa depan kepada masyarakat sekitar. Walaupun demikian, masyarakat masih mengeluhkan kenyamanan hidup di sekitar pabrik tersebut.
\end{abstract}

Kata Kunci: corporate social responsibility, public relations, media massa 


\section{A. PENDAHULUAN}

Industrialisasi merupakan salah satu upaya untuk meningkatkan kualitas hidup, dengan cara memperluas lapangan kerja, menunjang pemerataan pembangunan, meningkatkan pendapatan dan kesejahteraan masyarakat (Rondinelli, 2013). Industrialisasi adalah bagian dari proses modernisasi masyarakat melalui pengembangan ekonomi, sehingga memunculkan pekerjaan yang semakin beragam (spesialisasi), gaji, dan penghasilan yang semakin tinggi dengan berdasarkan pada teknologi yang semakin tinggi dan pesatnya akumulasi modal (Mabogunje, 2015).

Daerah Bekasi merupakan salah satu kota yang terkenal dengan industrinya. Banyak sekali industri yang berkembang di Bekasi mulai dari industri rumahan yang sangat kecil, pabrik yang sedang dan menengah, industri yang besar, bahkan sampai industri energi. Sementara itu, mayoritas penduduk Desa Muara Bakti ini menggantungkan hidupnya dari hasil bertani, kehidupan sehari-hari tidak lepas dari kegiatan bekerja di sawah. Di desa ini, keterampilan untuk bekerja di sawah merupakan keterampilan yang diperoleh sejak kecil, karena pekerjaan pertanian merupakan warisan turun temurun sehingga perasaan keterikatan dengan tanah pertanian sangat kuat. Oleh karena itu, sebelum Industrialisasi, pola mata pencaharaian masyarakat Desa Muara Bakti hampir memiliki kesamaan, yaitu sebagai petani. Akan tetapi dengan kehadiran kawasan industri pilihan terhadap pekerjaan menjadi beragam dan berubah. Masyarakat kebanyakan tidak lagi berkutat hanya pada petani, tetapi lebih memilih sebagai buruh pabrik atau pekerja pabrik.

Salah satu daerah yang terkena imbas dari dari proses industrialisasi adalah Desa Muara Bakti. Di desa ini telah banyak lahan pertanian yang berubah alih fungsi lahan menjadi industri. Tahun 2010 pertama kali didirikan industri pembangkit listrik 
di Desa Muara Bakti Kecamatan Babelan Kabupaten Bekasi. Desa Muara Bakti merupakan bagian dari Kabupaten Bekasi yang mempunyai iklim sangat panas karena selain banyaknya industri yang berkembang dan padatnya penduduk, Bekasi juga berdekatan dengan laut. Pada awalnya Desa Muara Bakti merupakan desa yang dikelilingi dengan hamparan sawah sebelum adanya industri uap batu bara. Dengan adanya industri sebagian sawah tersebut menjadi lahan pembangunan industri.

Dilihat dari segi ekonomi, sebagian masyarakat ada yang diuntungkan dan ekonomi masyarakat lebih meningkat setelah adanya industri tenaga uap batu bara, karena dengan adanya industri tersebut masyarakat membuka atau mendirikan tokotoko dan warung-warung kecil di sepanjang jalan dekat industri tersebut. Dilihat dari segi sosial masyarakat setelah adanya industri di Desa Muara Bakti, kehidupan sosial masyarakat mengalami perubahan. Masyarakat yang dahulu tenang dan nyaman tinggal di desa mereka, sekarang setelah adanya industri masyarakat dilanda suara bising, debu, dan banyak mobil-mobil besar yang keluar masuk kawasan perdesaan.

\section{B. TINJAUAN TEORI}

Perluasan dan peningkatan sektor industri mempunyai pengaruh yang sangat besar terhadap peningkatan alokasi investasi (penanaman modal). Dengan adanya tuntutan peningkatan laju pertumbuhan ekonomi yang tinggi di sektor industri diharapkan dapat menuju sasaran-sasaran yang akan dicapai yaitu dalam rangka menunjang pembangunan pada umumnya yang dapat menghasilkan devisa bagi negara. Pembangunan industri itu sendiri dilakukan secara terencana dan bertahap agar industri dalam struktur perekonomian dapat bertahan dengan baik (McKinnon, 2010). Munculnya industri tidak hanya unsur pokok bagi pertumbuhan ekonomi secara mendasar, tetapi juga mengarah pada penciptaan suatu budaya umum. Proses ini 


\section{ART IKEL}

berlangsung secara kontinu yang selalu melibatkan faktor ekonomi, urbanisasi, transformasi sosial budaya menuju keseimbangan struktur sosial yang baru (Anwar, R. K., Rusmana, A., \& Rahman, M. T., 2018).

Sementara itu, untuk memediasi antara perusahaan industri dengan masyarakat sekitarnya diperlukan tenaga humas. The British Institute of Public Relations mendefinisikan humas sebagai "an effort to establish and maintain mutual understanding between organization and it's public" (suatu upaya untuk membangun dan mempertahankan saling pengertian antara organisasi dan publiknya) (Austin et.al., 2012).

Frank Jefkins dalam Papasolomou, I., \& Melanthiou, Y. (2012) memberi batasan humas, yaitu sesuatu yang merangkum keseluruhan komunikasi yang terencana, baik itu kedalam maupun keluar antara suatu organisasi dengan semua khalayaknya dalam rangka mencapai tujuan-tujuan spesifik yang berlandaskan pada saling pengertian. Strategi humas atau public relations biasanya digunakan untuk membantu perusahaan mencapai tujuannya di setiap keadaan.

Strategi Public Relations terdiri dari: publikasi, event, berita, keterlibatan pada masyarakat, menginformasikan atau membangun image, lobbying dan negosiasi, dan tanggung jawab sosial (Szondi, 2010).

\section{METODE}

Metode yang digunakan dalam penelitian ini adalah metode deskriptifkualitatif. Demikian karena kajian ini memusatkan perhatian pada masalah-masalah yang ada pada saat penelitian dilakukan atau masalah yang bersifat aktual, serta menggambarkan fakta-fakta tentang masalah yang diselidiki sebagaimana adanya serta diiringi dengan interpretasi rasional yang adequate (Sekaran \& Bougie, 2016). Dengan 
metode ini digambarkan suatu analisis secara utuh sebagai suatu kesatuan yang terintegrasi (Teddlie, C., \& Tashakkori, A. 2009). Caranya dengan mengumpulkan, dan menganalisa data-data yang ada kaitannya dengan obyek kajian (Bernard, H. R., Wutich, A., \& Ryan, G. W. 2016). Sumber data utama dalam penelitian kualitatif ialah kata-kata dan tindakan (Lasch et.al., 2010). Kata-kata dan tindakan di sini merupakan sumber data yang diperoleh dari pengamatan akan aktivitas organisasi dan mewawancarai mereka yang terlibat langsung dengan keberadaan PT. Cikarang Listrindo tenaga uap batu bara, baik para pekerja humas PT tersebut, pihak pers, para aparat, dan masyarakat Desa Muara Bakti.

\section{HASIL DAN PEMBAHASAN}

Terletak sekitar $45 \mathrm{~km}$ di sebelah tenggara Jakarta, Cikarang Listrindo membangun pembangkit listrik pertamanya di jantung Kawasan Industri Jababeka pada tahun 1992 dan sejak saat itu Perseroan Terbatas tersebut telah mengatur perkembangan industri dengan menyediakan pasokan listrik berkualitas kepada para pelanggannya. Lebih dari 2.000 pelanggan dalam 5 kawasan industri memberikan kepercayaan kepada Cikarang Listrindo untuk menyediakan tenaga listrik yang handal dan stabil. Pelanggan Perseroan tersebut mencakup perusahaan manufaktur lokal dan asing atau multinasional yang bergerak dalam beberapa sektor industri antara lain otomotif, elektronik, plastik, makanan dan kimia. Pelanggan tersebut diantaranya adalah perusahaan blue-chip seperti PT Astra Honda Motor, PT Mattel Indonesia, PT Omron Manufacturing of Indonesia, PT Komatsu Undercarriage Indonesia, PT Mayora Indah, PT Aisin Indonesia, PT Yanmar Indonesia, PT AJE Indonesia, PT Mitsubishi Electric Automotive, PT Enkei Indonesia, PT Jotun Indonesia, PT Kao Indonesia, PT Kansai Paint Indonesia, PT Kayaba Indonesia dan PT Showa Indonesia 
ART IKEL

E-ISSN: $2615-5028$

Manufacturing serta banyak perusahaan lokal terkemuka lainnya (http://www.listrindo.com/id/beranda/ [26/7/2018]).

Untuk memenuhi permintaan pelanggan kawasan industri yang terus tumbuh dan menciptakan sistem pasokan listrik yang lebih handal, Cikarang Listrindo terus melakukan investasi untuk meningkatkan kapasitasnya. Pada tahun 2015, Cikarang Listrindo mengoperasikan pembangkit listrik tambahan sebesar 109MW yang terletak di Kawasan Industri Megalopolis Manunggal 2100. Saat ini Cikarang Listrindo memiliki kapasitas pembangkit terpasang gabungan sebesar 864 MW. Program pengembangan untuk meningkatkan kapasitas terpasang menjadi 1.144 MW sedang dalam proses. Selain memenuhi permintaan pelanggan di kawasan industri, Perseroan tersebut juga memasok listrik ke jaringan listrik nasional yang dimiliki PLN. Perseroan tersebut berkomitmen untuk memberikan pelayanan terbaik kepada para pelanggannya dalam memenuhi kebutuhan listrik yang stabil dan handal. Pasokan listrik yang lancar memberikan manfaat signifikan bagi pelanggan dalam mendukung kegiatan operasional dan menunjukkan tingkat keandalan yang tertinggi di pasar energi Indonesia (http://www.listrindo.com/id/beranda/ [26/7/2018]).

Pada tahun 2010, PT Cikarang Listrindo mulai pembangunan di Desa Muara Bakti dan menjadi PT Industri yang terbesar di Desa Muara Bakti Kecamatan Babelan Kabupaten Bekasi, karena sebelumnya hanya ada PT industri kecil atau rumahan saja. PT Cikarang Listrindo pun memberikan tanggung jawab sosial perusahaan (Corporate Social Responsibility) yang memiliki berbagai bentuk tanggung jawab terhadap seluruh pemangku kepentingan yang diantaranya konsumen, karyawan, pemegang saham dan lingkungan dalam segala aspek ekonomi, sosial, dan lingkungan. Salah satu tanggung jawab sosial perusahaan tersebut adalah membangun sekolah dan masjid di Desa 
Muara Bakti dan Buni Bakti. Dalam sistem industri pun, ada banyak aktor yang berperan dalam menggerakan sistem. Aktor tersebut adalah insan-insan industri yang ada pada berbagai sector seperti aktor swasta untuk investasi pembangunan PT Cikarang Listrindo, dan pemerintah Kota Bekasi yang memberi ijin untuk melancarkan pembangunan industri tersebut (Wawancara ND, aparat Desa Muara Bakti, 3 Mei 2018).

PT Cikarang Listrindo pada tahun 2017, pembangkit listrik berbahan bakar batu bara di Desa Muara Bakti ditambahkan dengan memakai dua boiler Valmet (circulating fluidized bed) dan dua turbin uap Siemens yang memberikan total kapasitas pembangkit terpasang sebesar $280 \mathrm{MW}$, meningkatkan kapasitas interkoneksi ketiga pembangkit listrik Perseroan menjadi sebesar 1.144 MW. Pembangkit listrik berbahan bakar batu bara di Desa Muara Bakti terkoneksi melalui jaringan transmisi $150 \mathrm{kV}$ yang membentang sepanjang 30km dan terdiri dari 101 menara (Wawancara MT, humas PT CL, 2 Mei 2018).

\section{Membawa Perubahan Masyarakat}

Desa Muara Bakti merupakan sebuah desa yang terletak dalam daerah Kecamatan Babelan, Kabupaten Bekasi, Provinsi Jawa Barat. Masyarakat di wilayah Desa Muara Bakti sebagaian besar merupakan penduduk pribumi, dengan jumlah penduduk sekitar 10,446 jiwa, dengan perincian laki-laki 5,253 orang, dan perempuan 5,193 orang. Masyarakat Desa Muara Bakti yang mayoritas bermata pencaharian di bidang pertanian, dan keadaan di Desa pun masih sangat jauh dari keadaan pembangunan untuk meningkatkan perekonomian masyarakat (Monografi Desa Muara Bakti, 2018). 
Untuk menyadarkan masyarakat akan arti pentingnya perusahaan listrik, pihak PT Cikarang Listrindo mengandalkan tim humasnya. Sedangkan humas tidaklah sendirian menghadapi masyarakat. Humas juga mendengar suara masyarakat dari pihak media massa mengenai masyarakat sekitar yang secara ekonomis kurang maju. Adapun media massa tersebut rata-rata adalah media massa nasional yang mempunyai berita tentang Bekasi, terutama daerah sekitar Cikarang (Wawancara MT, humas PT CL, 2 Mei 2018).

Pihak Humas PT Cikarang Listrindo bekerja sama dengan pihak media telah berhasil menyadarkan masyarakat bahwa adanya PT tersebut dapat membantu menurunkan angka pengangguran dan meningkatkan perekonomian masyarakat Desa Muara Bakti maupun masyarakat luar. Karena banyak tenaga pekerja yang dibutuhkan untuk menyelesaikan proyek pembangunan P'T Cikarang Listrindo agar tepat waktu, dengan banyaknya penyerapan tenaga kerja secara tidak langsung banyak interaksi sosial yang terjadi, melalui interaksi ini pengalaman dan pengetahuan masyarakat akan bertambah akan dunia kerja. Dengan adanya pembangunan PT Cikarang Listrindo diterima baik oleh masyarakat Desa Muara Bakti meskipun masih ada beberapa yang pro dan kontra, hampir semua masyarakat tertarik untuk bekerja di PT tersebut (Wawancara NY, petugas keamanan PT Cikarang Listrindo, 21 Juli 2018).

Humas PT Cikarang Listrindo pun mengakui bahwa pembangunan industri tersebut tidak terlepas dari perubahan-perubahan yang terjadi pada Desa Muara Bakti, baik itu perubahan kondisi sosial, infrastruktur jalan, dan kebersihan lingkungan yang berubah. Maka dari itu kenyamanan masyarakat dan kebutuhan masyarakat harus dioptimalkan, seperti perbaikan jalan, lowongan pekerjaan, agar pengelola industri dan 
masyarakat tidak saling di rugikan. Karena pembangunan industri ada juga yang bersifat negatif (Wawancara MH, Masyarakat Sekitar, 3 Mei 2018).

Dari kenyataan adanya tanggapan yang negative itulah, kemudian pihak Humas PT Cikarang Listrindo bekerja sama dengan pihak media dan Karangtaruna Desa Muara Bakti melakukan upaya-upaya lobbying dan negosiasi agar kebutuhan dan keperluan kedua belah pihak berjalan lancar. Selain itu dengan berjalannya kordinasi membantu agar tidak terjadi kesenjangan dan tidak menimbulkan masalah, oleh sebab itu akan memberikan pengertian kepada masyarakat untuk mau bekerja bersama agar tidak ada pihak yang saling dirugikan. Dengan berjalannya kordinasi dan komunikasi akan membantu masyarakat dengan informasi bila nanti ada kembali lowongan pekerjaan yang diperlukan, secara tidak langsung PT Cikarang Listrindo mengutamakan masyarakat Desa Muara Bakti dibandingkan dengan masyarakat dari luar Desa Muara Bakti (Wawancara MT, humas PT CL, 2 Mei 2018).

\section{Corporate Social Responsibility (CSR)}

Corporate Social Responsibility (CSR) adalah suatu konsep atau tindakan yang dilakukan perusahaan sebagai rasa tanggung jawab perusahaan terhadap sosial maupun lingkungan sekitar dimana perusahaan itu berada. PT. Cikarang Listrindo bekerja sama dengan pemerintah Desa Muara Bakti dan Desa Buni Bakti, melakukan pembangunan sekolah dan masjid karena kedua lokasi Desa tersebut sangat dekat dengan lokasi PT Cikarang Listrindo. Hal itu dipandang sebagai tanggung jawab sosial perusahaan terhadap Desa (Wawancara MW, masyarakat, 25 Juli 2018).

Dapat dilihat bahwa masyarakat pun masih mempunyai nilai-nilai bahwa manusia harus senantiasa beribadah, berikhtiar untuk memperbaiki kehidupan dan 
tidak hanya beribadah saja, akan tetapi masyarakat masih membutuhkan pendidikan formal yang maju. Pendidikan memberikan nilai-nilai tertentu untuk manusia, terutama dalam membuka pikirannya serta menerima hal-hal baru dan juga bagaimana cara berpikir secara ilmiah. Di sini pihak Humas dan media massa telah menekankan bahwa adanya PT Cikarang Listrindo ini pun berdampak positif karena pihak PT pun memberikan kebijakan serta tanggung jawab terhadap lingkungan sekitar dengan adanya program CSR yang dapat membantu masyarakat baik dalam segi pendidikan maupun ekonomi (Wawancara MT, humas PT CL, 2 Mei 2018).

\section{Penyerapan Tenaga Kerja}

Menurut survey yang dilakukan oleh Humas PTCL, masyarakat sudah mempunyai pemikiran bahwa Pembangunan PT. Cikarang Listrindo yang terjadi di Desa Muara Bakti memberikan dampak positif, karena telah membuka lapangan kerja terutama untuk masyarakat Desa Muara Bakti (Wawancara MT, humas PT CL, 2 Mei 2018). Hal itu terkonfirmasi, misalnya diungkap seorang penduduk yang sudah bekerja: "Yaa saya bersyukur bisa membantu perekonomian orang tua saya dengan bekerja disini, awalnya lulus SMK saya bingung tidak dapat pekerjaan hampir dua tahun tapi setelah dibangunnya PT Cikarang Listrindo ini alhamdulillah saya bisa bekerja" (Wawancara IN, 25 juli 2018). Dan hal tersebut dikuatkan pula oleh AM selaku Kepala Desa Muara Bakti: Masyarakat Desa Muara Bakti sangat mendukung adanya PT. Cikarang Listrindo, karena mayoritas pekerja dari PT. Cikarang Listrindo ini masyarakat sekitar, dan masyarakat lainnya seperti yang tidak bekerja dapat bekerja kembali dan ada juga yang membuka usaha kuliner makanan di jalur utama jalan Desa 
Muara Bakti. Hasil ini pun meningkatkan perekonomian masyarakat terutama Desa Muara Bakti” (Wawancara AM, Kepala Desa Muara Bakti, 21 Juli 2018).

Adanya penyerapan tenaga kerja banyak masyarakat yang beralih dari mata pencaharian petani, pedagang, menjadi industri. Dengan penyerapan tenaga kerja ini memberikan dampak positif terutama mengurangi angka pengangguran di Desa Muara Bakti. Ketidakpuasan masyarakat terhadap bidang kehidupan yang berlangsung lama seperti mata pencaharian petani, dalam sebuah masyarakat berkemungkinan besar akan mendatangkan revolusi seperti berubahnya mata pencaharian untuk meningkatkan perekonomian. Jika dilihat dari penyerapan tenaga kerja PT Cikarang Listrindo ini pun membawa dampak positif bagi masyarakat sekitar khususnya dan masyarakat luar pada umumnya. Pers setempat pun melihat bahwa dengan adanya PT mengurangi tingkat pengangguran (Wawancara MT, humas PT CL, 2 Mei 2018).

\section{Future Outlook}

Menurut Kartasasmita, G., \& Stern, J. J. (2016) orientasi masa depan adalah bagaimana seseorang merumuskan dan menyusun visi kedepan dengan membagi orientasi jangka pendek, menengah, dan jangka panjang. Masyarakat Desa Muara Bakti banyak yang beroreintasi untuk masa depan. Salah satunya karena faktor sosial ekonomi dengan membuka jasa kost atau kontrakan, mendirikan toko, rumah makan, dan lain sebagainya. Hal ini seperti yang diungkapkan oleh Komariah: "Banyak masyarakat yang datang untuk bekerja disini, dan mengontrak rumah di Desa Muara Bakti, ini semua dapat meningkatkan perekonomian masyarakat sini. Yaah contohnya seperti ibu yang tadinya hanya sebagai petani sekarang ada sambilan berjualan makanan lumayan untuk menambah penghasilan sehari-hari, hasilnya pun cukup banyak kalau 
pekerja sedang istirahat maupun masyarakat yang lewat" (Wawancara KM, pedagang, 21 Juli 2018).

Dapat dilihat bahwa tugas Humas kepada masyarakat sekitar industri telah berjalan dengan baik. Sekarang ini, dengan adanya PT Cikarang Listrindo, masyarakat Desa Muara Bakti banyak yang berpikir ke depan untuk kehidupan yang lebih baik lagi, karena jika tidak dilakukan masyarakat akan mengalami ketertinggalan, maupun dari mata pencaharian yang sangat sulit untuk dicari, dan susahnya meningkatkan perekonomian. Masyarakat pun meningkatkan taraf ekonomi dengan berbagai cara dan mandiri seperti yang dipaparkan di atas bahwa dengan berdagang sebagai pekerjaan sambilan sangat membantu memenuhi kebutuhan sehari-hari.

Begitu pula, dengan adanya PT Cikarang Listrindo, sebagian masyarakat yang terlambat akan perkembangan ilmu pengetahuan dan tidak mengikuti era modern, hal ini pun dirasakan oleh masyarakat Desa Muara Bakti karena hanya beberapa pekerja yang memiliki kemampuan dan tenaga ahli saja yang dibutuhkan. Dan tidak adanya pemberdayaan atau pelatihan membuat masyarakat hanya terdiam dan mencari pekerjaan lain. Seperti yang diungkapkan seorang pekerja lokal: "Waktu awal pembangunan memang menjamin, karena masih banyak PT yang membutuhkan tenaga dalam pembangunannya. Tapi sekarang ini hanya orang yang mempunyai skill yang mungkin bisa bekerja di PT tersebut, masih banyak masyarakat yang belum mempunyai pekerjaan meski ada PT besar di daerah sendiri, semoga kedepannya ada pelatihan untuk masyarakat sini” (Wawancara HM, 25 Juli 2018).

Hal terakhir ini boleh jadi disebabkan hidup masyarakat tersebut terasing dan tertutup, dan kurangnya hubungan dengan masyarakat lain. Kehidupan terasing menyebabkan sebuah masyarakat tidak mengetahui perkembangan-perkembangan apa 
saja yang terjadi pada masyarakat lain yang mungkin akan dapat memperkaya kebudayaan sendiri maupun pengetahuan (Hatch, M. J. 2018). Seperti yang diungkapkan oleh Inglehart (2018), perubahan sosial dapat berubah dengan adanya kebudayaan, kebudayaan yang bekembang pada masyarakat dapat mempengaruhi kreativitas pada masyarakat pula.

Memang, memasukkan modernisasi seperti pengadaan industri energi ke masyarakat petani adalah yang cukup mengejutkan bagi masyarakat. Di sini pihak pembawa perubahan seperti PTCL akan dihadapkan pada kurangnya hubungan dengan masyarakat, perkembangan ilmu pengetahuan yang lambat, sikap masyarakat yang sangat tradisional, adanya kepentingan-kepentingan yang telah tertanam dengan kuat, rasa takut akan terjadinya kegoyahan pada integrasi kebudayaan, prasangka terhadap hal-hal baru atau asing atau sikap yang tertutup, hambatan-hambatan yang bersifat teologis, adat atau kebiasaan dan nilai bahwa hidup ini pada hakikatnya buruk dan tidak mungkin diperbaiki (Rahman, 2011). Namun demikian, pihak Humas PTCL tersebut sudah bisa membawakan kesadaran akan pentingnya mengikuti perubahan sekaligus mengikuti arus perubahan tersebut. Akhirnya masyarakat setempat menyadari hal-hal tersebut dan kemudian dapat menikmati pula porsi limpahan yang disediakan oleh PTCL.

Alhasil, Humas PTCL, dalam upayanya untuk mendekati masyarakat desa tempat PT itu berada telah melakukan brand image yang baik pada masyarakat tersebut. Di sini fungsi Humas pun ditegaskan kembali dengan fungsi marketingnya selain fungsi communicating (Putri, F. A., Sumartias, S., \& Sjoraida, D. F. 2018). Demikian karena apapun langkah Humas, itu berarti harga dari perusahaannya, karena Humas adalah etalase dari perusahaannya (Scott, D. M. 2015). 


\section{E. KESIMPULAN}

Berdasarkan hasil penelitian, maka dapat ditarik kesimpulan berikut:

1. Proses penerimaan masyarakat desa terhadap adanya industri PT Cikarang Listrindo pada awalnya dimulai dengan kampanye pers pihak humas PT tersebut terhadap masyarakat akan berharganya PT tersebut dan bahwa PT tersebut dapat membawa berkah pada masyarakat sekitarnya. Di sini pihak humasnya menunjukkan fungsinya yang membawakan publication, news, dan building image.

2. Semenjak kampanye humas di media massa, masyarakat desa di sekitar PT Cikarang Listrindo ini pun mengalami perubahan. Sekarang ini masyarakat petani banyak yang bekerja di bidang industri daripada di sawah. Di sini humas sudah melakukan community involvement.

3. Dari segi kesempatan (opportunity), humas PT Cikarang Listrindo sudah dapat mengkomunikasikan bahwa PT tersebut telah dapat mengurangi angka pengangguran. Di sini masyarakat Desa Muara Bakti banyak yang membuka usaha baru untuk meningkatkan taraf ekonomi, seperti membuka toko, tempat makan, kostan, dan lain sebagainya.

4. Upaya masyarakat dalam meningkatkan perekonomian setelah adanya PT Cikarang Listrindo bahwa yang sebelum adanya PT ini masyarakat Desa Muara Bakti hanyalah seorang pekerja petani yang hasilnya tidak menentu pendapatannya. Untuk mambantu perekonomian, masyarakat membuka usaha mikro seperti kuliner makanan, pertokoan, dan warung-warung kecil.

5. Humas PT Cikarang Listrindo pun telah dapat menunjukkan sebagai pihak yang piawai memberikan kenyamanan pada masyarakat. Di sini humas telah 
menunjukkan kepiawaiannya dalam bidang lobbying dan negosiasi dengan masyarakat sekitar PT itu berada, termasuk pemerintah desanya. Alhasil, humas PT tersebut telah menunjukkan dukungan PT untuk kebaikan semua.

6. Terakhir, humas PT Cikarang Listrindo telah menunjukkan sebagai pelaksana Corporate Social Responsibility (CSR) dengan kemampuannya yang mumpuni dalam menyalurkan bantuan dari PT tersebut pada fasilitas sosial seperti pembangunan sekolah dan masjid.

\section{DAFTAR PUSTAKA}

Anwar, R. K., Rusmana, A., \& Rahman, M. T. (2018). The Politics Of Information On Traditional Medical Practices In Bandung Barat. MIMBAR, Vol. No 1st (June) 2018 pp. 158-165, 34(1).

Austin, L., Fisher Liu, B., \& Jin, Y. (2012). How audiences seek out crisis information: Exploring the social-mediated crisis communication model. Journal of Applied Communication Research, 40(2), 188-207.

Bernard, H. R., Wutich, A., \& Ryan, G. W. (2016). Analyzing qualitative data: Systematic approaches. SAGE publications.

Hatch, M. J. (2018). Organization theory: Modern, symbolic, and postmodern perspectives. Oxford university press.

http://www.listrindo.com.

Inglehart, R. (2018). Culture shift in advanced industrial society. Princeton University Press. Kartasasmita, G., \& Stern, J. J. (2016). Reinventing Indonesia. World Scientific. 


\section{ART IKEL}

Lasch, K. E., Marquis, P., Vigneux, M., Abetz, L., Arnould, B., Bayliss, M., \& Rosa, K. (2010). PRO development: rigorous qualitative research as the crucial foundation. Quality of Life Research, 19(8), 1087-1096.

Mabogunje, A. (2015). The development process: A spatial perspective. Routledge.

McKinnon, R. I. (2010). Money and capital in economic development. Brookings Institution Press.

Papasolomou, I., \& Melanthiou, Y. (2012). Social media: Marketing public relations' new best friend. Journal of Promotion Management, 18(3), 319-328.

Putri, F. A., Sumartias, S., \& Sjoraida, D. F. (2018). Proses Rebranding Mal Grand Indonesia Oleh Departemen Marketing Communication PT Grand Indonesia. PRofesi Humas, 2(2), 102-118.

Rahman, M Taufiq. 2011. Glosari Teori Sosial. Bandung: Ibnu Sina Press.

Rondinelli, D. A. (2013). Development projects as policy experiments: An adaptive approach to development administration. Routledge.

Scott, D. M. (2015). The new rules of marketing and PR: How to use social media, online video, mobile applications, blogs, news releases, and viral marketing to reach buyers directly. John Wiley \& Sons.

Sekaran, U., \& Bougie, R. (2016). Research methods for business: A skill building approach. John Wiley \& Sons.

Szondi, G. (2010). From image management to relationship building: A public relations approach to nation branding. Place branding and public diplomacy, 6(4), 333-343.

Teddlie, C., \& Tashakkori, A. (2009). Foundations of mixed methods research: Integrating quantitative and qualitative approaches in the social and behavioral sciences. Sage. 